\title{
Development and Validation of Pedagogical Beliefs About Teaching Practices Questionnaire: A Cross-Continental Study
}

\author{
Lidon Moliner ${ }^{1}$, Aida Sanahuja ${ }^{2}$, Francisco Alegre ${ }^{3}$ \\ Jaume I University, Department of Pedagogy, Av. Sos Baynat no number 12071, Castellon, Spain. mmoliner@uji.es \\ Jaume I University, Department of Pedagogy, Av. Sos Baynat no number 12071, Castellon, Spain. asanahuj@uji.es \\ Jaume I University, Department of Pedagogy, Av. Sos Baynat no number 12071, Castellon, Spain. falegre@uji.es
}

Annotation. The aims of this study were to create and validate a questionnaire designed to assess schoolteachers' pedagogical beliefs according to 641 schoolteachers and 26 experts and analyse the results obtained therefrom. A seven-factor structure was defined for the questionnaire, and Cronbach's alpha was .91. Compared to their older, more experienced and male counterparts, younger, less experienced and female teachers, respectively, demonstrated more positive beliefs about factors such as classroom climate, the teacher's role and the student's role.

Keywords: schoolteachers, pedagogical beliefs, questionnaire.

\section{Introduction}

Teachers' pedagogical beliefs have been studied for several decades, but the definition of those beliefs still generates some controversy (Ertmer, 2005). Pioneer studies by Prawat (1992) and Samuelowicz and Bain (2001) led the way for dozens of research articles in the field, with analyses encompassing nearly all academic subjects, including mathematics (Barkatsas \& Malone, 2005; Gill et al., 2004; Raymond, 1997), science (Bryan, 2012; Hancock \& Gallard, 2004; Tsai, 2002), English (Debreli, 2012; Farrell \& Lim, 2005; Phipps \& Borg, 2009), music (Battersby \& Cave, 2014; Emmanuel, 2005; Thompson, 2007), history (Virta, 2002; Voet \& De Wever, 2016), reading (Richardson et al., 1991) and physical education (Chróinín \& O’Sullivan, 2016; Tsangaridou, 2017). 
At the same time, several authors have focused on a more general assessment in this field of research (Fives et al., 2015; Schraw \& Olafson, 2015; Thomas, 2013). Scholarly interest in identifying and quantifying these beliefs from a pedagogical and psychological perspective is high, as factors such as teachers' acceptance of technology (Teo \& Zhou, 2017), teacher burnout (Burić et al., 2019; Fives et al., 2007), student perceptions (Lee \& Branch, 2018), student academic performance (Glackin, 2016), teacher efficacy (Specht et al., 2016) and teacher well-being (Huang et al., 2019) may be greatly influenced by these beliefs.

\section{Literature Review}

What do we mean by pedagogical beliefs? To understand what the term 'pedagogical belief' refers to, the difference between a belief and knowledge must first be understood. Calderhead (1996) considered beliefs to generally refer to assumptions, commitments and ideologies and to imply a conviction about or assessment of the matter at hand (Koballa \& Crawley, 1985). Beliefs have a greater emotional component than knowledge and are based on evaluations and judgments. Conversely, knowledge is based on objective facts (Pajares, 1992). Beliefs play a much greater role in decision-making than acquired knowledge (Solis, 2015). To illustrate, two teachers with the same (or similar) knowledge about cooperative learning may have different beliefs about its effectiveness in the classroom. Moreover, the teacher who holds negative beliefs about the benefits of cooperative learning will not be likely to propose cooperative methodologies in the classroom. As this example illustrates, teachers' beliefs are decisive in their organisation of activities to be carried out in the classroom and are strongly tied to the teaching strategies implemented in each session (Mansilla \& Beltrán, 2013; Solis, 2015). Indeed, teachers' beliefs about teaching, learning and their students affect their teaching practices (McCombs \& Whisler, 1997) and are also closely related to and impact student learning (Trigwell \& Prosser, 1991); that is, students' academic performance is influenced by the beliefs of their teacher (Solis, 2015). In addition, a teacher's perspective on such beliefs is also a determining factor in the choice of teaching practices. For example, traditional pedagogical beliefs are teacher-centred, while constructivist pedagogical beliefs focus on the student as the protagonist of the teaching and learning process (Deng et al., 2014).

Teaching practices based on constructivism approaches stress the need to create learning environments that stimulate self-regulated and active learning, acknowledge differences between students and connect to authentic and real-life contexts (de Kock et al., 2004; Shuell, 1996). This conceptualisation of teaching practices from a constructivist viewpoint is in line with practices based on inclusive education. From this perspective, the lessons are responsive to student diversity. Students are encouraged to be actively involved in all aspects of their education, which draws on their knowledge and experience gained outside of school (Booth \& Ainscow, 2000). 
Another important point related to this topic is the relation between teachers' practices and self-efficacy, which has been analysed in the last decade (Caprara et al., 2006; Dellinger et al., 2008; Tschannen-Moran \& Hoy, 2007). In pedagogical terms, self-efficacy may be defined as teachers' individual beliefs in their own capacities to execute actions and behaviours necessary to foster specific learning by their students (TschannenMoran \& Johnson, 2011). Self-efficacy is usually linked to the teacher's own motivation, behaviour, and social environment, among other factors (Granziera \& Perera, 2019; Oppermann et al., 2019).

In the literature, oftentimes, the instruments used to assess teachers' beliefs were not validated with sufficient rigor or were not validated at all (Brackett et al., 2012). To this purpose, a questionnaire appropriate for an international audience was developed for this research, and the information obtained through its application may be used by researchers in the field across the world from both pedagogical and psychological perspectives. The technical validity of the instrument was ensured by means of validity and reliability as well as exploratory and confirmatory factor analyses.

The objectives of this study were twofold: 1) to create and validate a questionnaire that could examine schoolteachers' pedagogical beliefs and 2) to analyse the results obtained after administering the questionnaire. To achieve these objectives, we proposed the following research questions:

- What are schoolteachers' pedagogical beliefs on teaching practices?

- Do statistically significant differences exist in schoolteachers' pedagogical beliefs on teaching practices based on years of experience, gender, employment status and background?

\section{Materials and Methods}

\section{Questionnaire Design}

The questionnaire was developed following procedures provided by educational psychology researchers (Duchesne \& McMaugh, 2018; Duckworth \& Yeager, 2015; Kline, 2015). According to these scholars, the first step is to review the literature on validated questionnaires in the field. Hence, several questionnaires related to teachers' beliefs about teaching and learning were examined (Beswick et al., 2019; Crosswaite \& Asbury, 2019; Kurup et al., 2019; Lotter et al., 2018; O’Neal et al., 2017). Following this review, an initial version of the questionnaire appropriate for an international audience was designed (Marshall \& Cox, 2008). Considering findings from previous studies in the field, a 7-factor structure was developed, and 6 items were included for each factor, for a total of 42 items. The seven defined factors by which teachers' beliefs would be assessed were as follows: (1) motivation, (2) evaluation, (3) socioemotional aspects, (4) classroom 
climate, (5) teacher's role, (6) methodology and (7) student's role. Teacher responses for each item followed a 5-point Likert-type scale $(1=$ strongly disagree, $2=$ disagree, $3=$ indifferent, 4 = agree, $5=$ strongly agree). In this sense, the higher the score, the higher the level of beliefs for each factor.

\section{Questionnaire Validation}

The initial version of the questionnaire was submitted for expert review (Oluwatayo, 2012) by educational authorities from European, North American, and South American universities who were selected based on their published works in high impact journals in the field of teachers' beliefs using the Delphi Method (Haynes \& Shelton, 2018). The 26 experts who participated were contacted by email, and anonymity of their responses was guaranteed. They were instructed to complete a Google Forms questionnaire following the Lawshe method (Baghestani et al., 2019) to validate each item of the initial version of the teachers' questionnaire. Using a 3-point scale, the experts evaluated each item as not necessary (1), useful but not essential (2) or essential (3). Based on these expert ratings, each item was awarded a content validity ratio (CVR) using a mathematical expression defined in Baghestani et al. (2019). A CVR cut-off value of .51 for a .01 level of significance for a two-tailed test, provided by Wilson et al. (2012), was applied to exclude items from the final version of the questionnaire. The CVR values and total scores awarded for each item by the 26 experts are shown in Table 1. Items excluded due to a CVR value lower than .51 are marked with an asterisk.

\section{Table 1}

CVR and Expert Scores for Each Initial Questionnaire Item

\begin{tabular}{|c|c|c|c|c|c|c|c|c|c|c|c|c|c|c|}
\hline \multirow[t]{2}{*}{ Item } & \multicolumn{3}{|c|}{$\begin{array}{l}\text { Expert } \\
\text { Scores } \\
\end{array}$} & \multirow[t]{2}{*}{$\begin{array}{l}\text { Item } \\
\text { CVR }\end{array}$} & \multicolumn{2}{|l|}{ Item } & \multicolumn{2}{|c|}{$\begin{array}{l}\text { Expert } \\
\text { Scores }\end{array}$} & \multirow[t]{2}{*}{$\begin{array}{l}\text { Item } \\
\text { CVR }\end{array}$} & \multicolumn{2}{|c|}{ Item } & \multicolumn{2}{|c|}{$\begin{array}{l}\text { Expert } \\
\text { Scores }\end{array}$} & \multirow[t]{2}{*}{$\begin{array}{l}\text { Item } \\
\text { CVR }\end{array}$} \\
\hline & 1 & 2 & 3 & & & 1 & 2 & 3 & & & 1 & 2 & 3 & \\
\hline 1 & 0 & 4 & 22 & .69 & $15^{\star}$ & 8 & 9 & 9 & -.31 & $29^{*}$ & 2 & 6 & 18 & .38 \\
\hline 2 & 0 & 3 & 23 & .77 & 16 & 0 & 0 & 26 & 1 & 30 & 0 & 1 & 25 & .92 \\
\hline 3 & 1 & 4 & 21 & .62 & 17 & 1 & 3 & 22 & .69 & $31^{\star}$ & 3 & 9 & 14 & .08 \\
\hline $4^{\star}$ & 6 & 7 & 13 & 0 & 18 & 0 & 2 & 24 & .85 & $32^{*}$ & 3 & 8 & 15 & .15 \\
\hline 5 & 1 & 3 & 22 & .69 & $19^{*}$ & 4 & 5 & 15 & .15 & 33 & 0 & 3 & 23 & .77 \\
\hline $6^{*}$ & 5 & 9 & 12 & -.08 & $20^{\star}$ & 4 & 9 & 13 & 0 & $34^{*}$ & 6 & 7 & 13 & 0 \\
\hline 7 & 1 & 1 & 24 & .85 & $21^{\star}$ & 7 & 5 & 14 & .08 & 35 & 1 & 3 & 22 & .69 \\
\hline 8 & 0 & 1 & 25 & .92 & 22 & 1 & 3 & 21 & .62 & 36 & 0 & 2 & 24 & .85 \\
\hline $9^{*}$ & 8 & 7 & 11 & -.15 & $23^{*}$ & 9 & 8 & 9 & -.31 & 37 & 1 & 1 & 24 & .85 \\
\hline $10^{*}$ & 5 & 7 & 14 & .08 & 24 & 0 & 4 & 22 & .69 & 38 & 0 & 0 & 26 & 1 \\
\hline 11 & 0 & 2 & 24 & .85 & 25 & 0 & 3 & 23 & .77 & 39 & 1 & 5 & 21 & .62 \\
\hline 12 & 0 & 1 & 25 & .92 & $26^{*}$ & 6 & 5 & 15 & .15 & 40 & 2 & 4 & 22 & .69 \\
\hline $13^{\star}$ & 6 & 9 & 10 & -.23 & $27^{\star}$ & 4 & 7 & 15 & .15 & 41 & 0 & 2 & 24 & .85 \\
\hline 14 & 0 & 3 & 23 & .77 & 28 & 0 & 0 & 26 & 1 & 42 & 0 & 5 & 21 & .62 \\
\hline
\end{tabular}


As a result of the validation process, 16 items were excluded, leaving 26 of the original 42 items remaining. The final version of the questionnaire used for the study is included in the appendices.

\section{Data Collection and Participants}

Data collection was carried out using the Google Forms tool. The participants for this phase of the research were enrolled in a massive online open course (MOOC) on 'the inclusive classroom today' (2nd edition). This course took place from October to November 2018; the link to the final version of the questionnaire was provided during the course on the participants' online platform. Those interested were invited to answer voluntarily; the confidentiality of their responses was guaranteed. In addition to responding to the questionnaire's items, respondents were asked to indicate, by category, their age (less than 23 years, between 23 and 26 years, between 27 and 30 years or more than 31 years) and years of experience in the field (less than 1 year, between 1 and 3 years, between 4 and 7 years or more than 8 years), as well as their employment status (employed or unemployed), their gender (male or female) and their region (North America, South America, or Europe). Thus, access to the study sample was non-probabilistic, and sampling can be considered intentional or convenience (Aven et al., 2013; Etikan et al., 2016). Descriptive data on the 641 schoolteachers who participated in the study are reported in Tables 2 and 3.

Table 2

Participants by Employment Status, Age and Gender

\begin{tabular}{cccccccc}
\hline \multicolumn{2}{c}{ Gender } & \multicolumn{2}{c}{ Employment status } & \multicolumn{4}{c}{ Age } \\
\hline Male & Female & Employed & Unemployed & $<\mathbf{2 3}$ & $\mathbf{2 3 - 2 6}$ & $\mathbf{2 7 - 3 0}$ & $>\mathbf{3 1}$ \\
\hline 267 & 374 & 208 & 433 & 19 & 133 & 119 & 370 \\
\hline
\end{tabular}

Table 3

Participants by Years of Experience and Region

\begin{tabular}{ccccccc}
\hline \multicolumn{3}{c}{ Years of experience } & \multicolumn{3}{c}{ Region } \\
\hline$<\mathbf{1}$ & $\mathbf{1 - 3}$ & $\mathbf{4 - 7}$ & $\mathbf{8}$ & North America & South America & Europe \\
\hline 122 & 101 & 120 & 298 & 129 & 205 & 307 \\
\hline
\end{tabular}

\section{Reliability Analysis of the Questionnaire}

Several analyses were conducted using SPSS software version 25 to determine the reliability of the questionnaire. Cronbach's alpha for the whole questionnaire, Cronbach's alpha if item was deleted and Spearman-Brown and Guttman Split-Half Coefficient were 
calculated (Drost, 2011; McCrae et al., 2011). These tests showed consistent results with a Cronbach's alpha coefficient of .91. In addition, if any of the 26 items were deleted from the questionnaire, the global Cronbach's alpha did not improve, and a Spearman-Brown and Guttman Split-Half Coefficient of .81 was found. For each of the factors, the Cronbach's alpha was as follows: F1-motivation: 0.93; F2-evaluation: 0.89; F3-socioemotional aspects: 0.94; F4-classroom climate: 0.79; F5-teacher's role: 0.88; F6-methodology: 0.90; F7-student's role: 0.92 .

\section{Exploratory and Confirmatory Factor Analyses}

Exploratory and confirmatory factor analyses were conducted to test the appropriateness of the seven-factor structure. SPSS software version 25 was used for the exploratory factor analysis, and EQS 6.3 software was used for the confirmatory factor analysis. First, the suitability of performing an exploratory factor analysis was assessed using the Kaiser-Meyer-Olkin Measure of Sampling Adequacy and Bartlett's Test of Sphericity (Osborne et al., 2008). Both tests showed adequate results, as an .88 value for the Kaiser-Meyer-Olkin Measure of Sampling Adequacy and a Bartlett's test of sphericity value of 3756.51 were reached.

The exploratory factor analysis was performed by means of a varimax rotation of principal axes factors (Gerbing \& Hamilton, 1996). The Kaiser method was used so that only eigenvalues greater than one were considered (Osborne, 2015). The analysis showed a seven-factor structure in which $71.23 \%$ of the cumulative variance was explained by these factors. Hence, the confirmatory factor analysis was performed, maintaining the seven-factor structure as indicated and associating each factor with its corresponding items.

Table 4

Exploratory Factor Analysis

\begin{tabular}{cccc}
\hline Component & Total & \% of Variance & Cumulative \% \\
\hline 1 & 5,35 & 24,95 & 24,95 \\
2 & 1,68 & 9,67 & 34,62 \\
3 & 1,29 & 8,05 & 42,67 \\
4 & 1,22 & 7,74 & 50,41 \\
5 & 1,12 & 7,32 & 57,74 \\
6 & 1,09 & 6,83 & 64,57 \\
7 & 1,06 & 6,66 & 71,23 \\
\hline
\end{tabular}

For the confirmatory factor analysis, the Bentler Comparative Fit Index (CFI) and Joreskog-Sorbom Fit Index (GFI) were used as goodness-of-fit indices, while chi-square divided by degrees of freedom ( $\chi 2 / \mathrm{df})$ and root-mean-square residual (RMR) were used 
as badness-of-fit indices. To confirm a suitable structure, according to Yuan et al. (2016), CFI and GFI values should be .9 or greater (the greater, the better), RMR should be 0.06 or lower and $\chi 2 / \mathrm{df}$ should be lower than 4 (the lower, the better). All these requirements were met for the four parameters, confirming the consistency of the factor structure.

\section{Table 5}

Confirmatory Factor Analysis

\begin{tabular}{ccccc}
\hline Model & RMR & $\chi^{2} / \mathbf{d f}$ & CFI & GFI \\
\hline Seven-factor structure & .04 & 2.05 & .92 & .93 \\
\hline
\end{tabular}

\section{Descriptive and Inferential Statistical Analysis}

Descriptive and inferential analyses of the data were carried out using SPSS version 25. First, a descriptive analysis was performed at a global level (average scores by factors, by age groups, by years of experience, by gender, by employment status, and by region). Subsequently, analyses of variance (ANOVAS) were carried out for those variables for which more than two options existed - that is, factors, years of experience, age, and region (Yigit \& Mendes, 2018). ANOVAs only indicate if statistically significant differences exist among the groups, but not which groups present such differences. Hence, ANOVAS were complemented with Scheffe's tests where significant statistical differences were reported to identify the specific groups between which said differences existed. Likewise, with the same goal of detecting differences in the variables for which only two groups existed (gender and employment status), student $t$-tests were conducted (Lakens, 2017). In addition, correlations between factors were examined using Pearson's correlation coefficient (Kelley et al., 2019).

Based on the size of the study sample and its psychoeducational nature, only those differences of means with $p<.01$ levels of significance were considered statistically significant (Connolly, 2007; Reich, 2005). In addition, only those correlations between factors greater than .5 were considered significant (Bishara \& Hittner, 2015; Osborne, 2003).

\section{Results}

Strong correlations were found among the motivation, classroom climate, and student's role factors: a Pearson's correlation coefficient of .58 was reported between the motivation and classroom climate factors; $r=.53$ between the motivation and student's role factors; and $r=.51$ between the classroom climate and student's role factors. No other statistically significant correlations between factors were reported. Statistically significant differences were reported for scores among factors $(F=89.73)$. In this context, Scheffe's test showed that scores for motivation, socioemotional aspects, and methodology factors 
were significantly greater than those for the evaluation, classroom climate, teacher's role, and student's role factors.

\section{Figure 1}

Scores by Factor

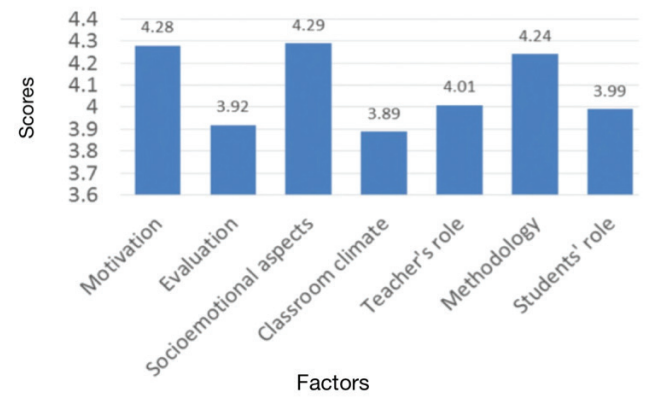

Figure 2

Scores by Region

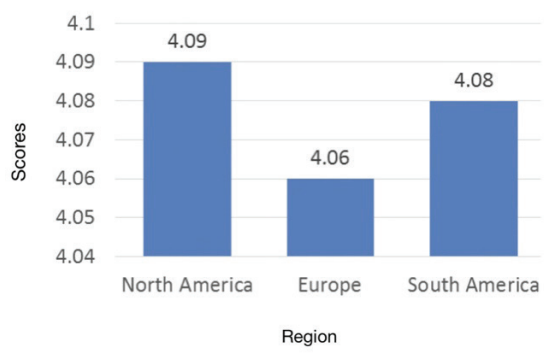

No statistically significant differences were found overall $(F=0.01, p=.97)$, or by any of the seven factors, between North American, South American, and European teachers' beliefs.

Statistically significant differences were reported when analysing responses according to the ages of the respondents $(F=3.97)$ and their years of experience $(F=3.99)$. For example, Scheffe's test showed that overall scores for teachers 26 years old or younger and for those with three years of experience or less were significantly greater than for their elder and more experienced peers (see Figures 3 and 4). An additional analysis by factors revealed that classroom climate $(F=4.05 ; F=4.11)$, teacher's role $(F=3.92$; $F=4.10)$ and student's role $(F=4.11 ; F=3.99)$ were the factors in which those differences were statistically significant.

Figure 3

Scores by Teacher Age

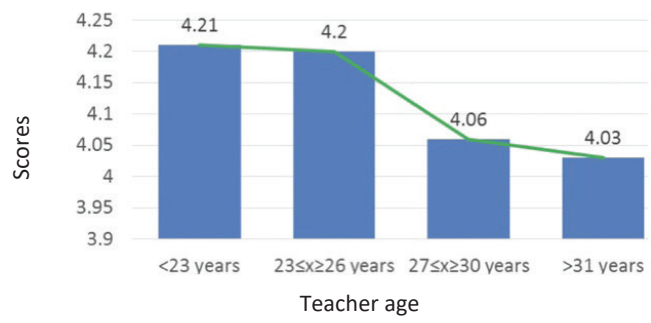

Figure 4

Scores by Teaching Experience

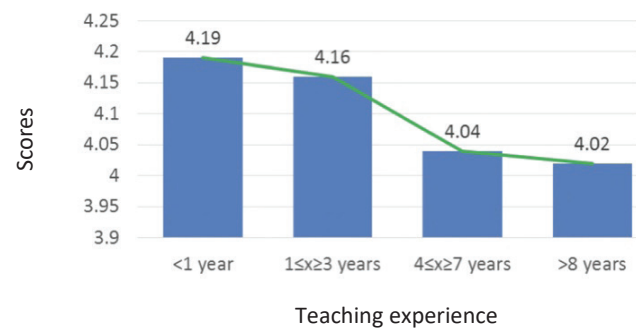

No statistically significant differences were reported regarding employment status $(t=1.25, p=.26)$. Statistically significant differences were reported by gender $(t=3.28)$, as females showed significantly higher scores than males. The additional analysis by factors 
with the gender variable revealed that, as with the variables of age and years of experience, classroom climate $(t=3.10)$, teacher's role $(t=3.25)$, and student's role $(t=3.12)$ were the factors in which those differences were statistically significant.

\section{Figure 5}

Scores by Employment Status

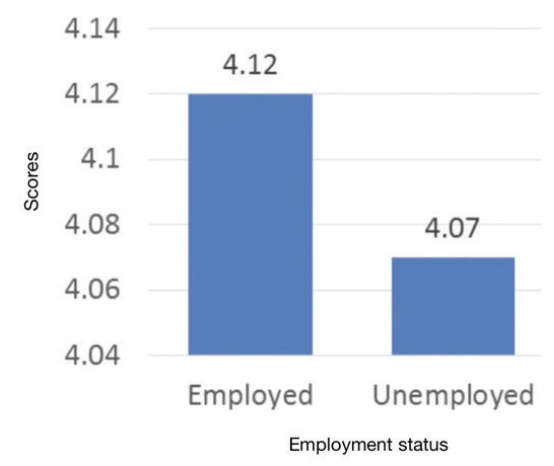

Figure 6

Scores by Gender

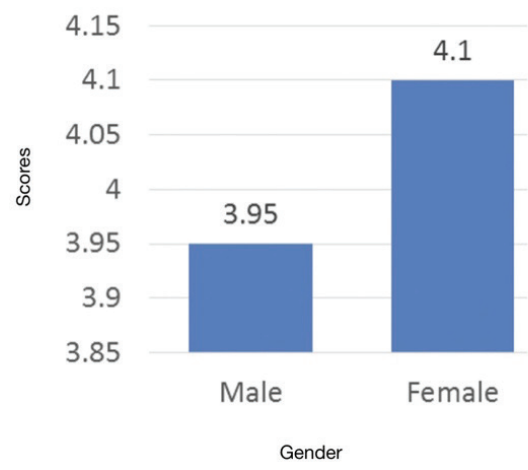

\section{Discussion and Conclusions}

The high global scores detected in this study regarding teachers' beliefs are in line with the findings from other research related to this field recently documented in the literature (Aragona-Young \& Swayer, 2018; Gralewski, 2019; Sak et al., 2018). These scores can be understood by the purely vocational character that is always linked to teaching, so finding a person with negative beliefs that are formed or professionally dedicated to issues related to teaching is difficult (Warwas \& Helm, 2018). In addition, the important differences found between the factors have also been reported in other recent studies. For example, authors such as Rubie-Davies (2015) and Oder and Eisenschmidt (2018) showed important differences between beliefs about classroom climate, motivation, methodology and teacher's role. Similarly, Barnes et al. (2015) referred to the differences that arise between teachers' beliefs regarding evaluation and their beliefs regarding methodology. According to these authors, these differences in scores between factors are justified for two main reasons: the environment in which teachers work and the level of independence they are given. For instance, working with problematic students may seriously affect beliefs about some factors, such as classroom climate, the teacher's role or the student's role, from the psychological perspective of the teacher (Tam, 2015). Also, as Santos and Miguel (2019) asserted, teachers often are not restricted in their choice of teaching methodology, but the same is not true for evaluation, as assessment methods are often established by the school educational department or other educational institutions. Hence, differences in 
teachers' beliefs regarding methodology and evaluation, as well as between other factors, are common and logical. A similar discussion may ensue when analysing the strong correlations found among teachers' beliefs regarding motivation, the student's role, and classroom climate. Previous research by Rubie-Davies and Peterson (2010), Köğce (2017), and Alansari and Rubie-Davies (2019) had already determined the existing relationships among teachers' beliefs on these factors. In agreement with what has been mentioned previously, these authors determined that the teaching environment is vital with respect to teachers' beliefs regarding these factors. Students with a good attitude towards learning may be easily motivated, so the classroom climate will probably be better (or easier to improve) in this context, significantly affecting teachers' beliefs.

The progressive decline in scores according to age and years of teaching experience indicated in the results has also been previously documented in other studies, such as Collie et al. (2015), Lev et al. (2018), and Bereczki and Karpati (2018). According to these authors, factors such as stress or job satisfaction may have a significant influence on teachers' psychological level over time. The fact that the results of this work regarding teachers' beliefs for the factors classroom climate, teacher's role, and student's role were particularly low for the elder and more experienced teachers supports this statement (Dubbeld et al., 2019; Shahzad et al., 2017; Walker \& Graham, 2019). In line with previous studies, many of the surveyed teachers who had more than 4 years of experience or were at least 31 years old may have already at some point encountered complicated educational situations regarding students' attitudes or behaviours, which would have significantly influenced their beliefs over time (Blazar \& Kraft, 2017; Peterson et al., 2016).

The differences found between males and females have also been previously documented in other studies (Berger \& Lê Van, 2019; Sak et al., 2015). As indicated by Specht et al. (2016), these differences may be explained by the more inclusive nature of females compared to males. In this sense, female schoolteachers are more sensitive to students' integration and well-being in class (Bernard, 2016; Tella, 2017). The higher scores for females regarding their beliefs on factors such as classroom climate or student's role support these results.

The non-influence of the employment situation on teachers' beliefs agrees with results obtained in other studies, such as those of Skaalvik and Skaalvik (2017) and Reichert and Torney-Purta (2019). The fact that a schoolteacher is currently unemployed does not necessarily indicate that teacher has not worked before or is not up to date with regional educational issues, which explains the similarities in the scores.

The similarity in scores for North American, South American, and European schoolteachers aligns with the findings of previous international or intercontinental studies in the field (Bauman \& Del Río, 2005; Little et al., 2019; Roose et al., 2019; Sharma \& Sokal, 2015; Sharma et al., 2018; Yan, 2018). Some of the authors of these studies have proposed that the similarities may be explained by the fact that, despite the important cultural differences between continents and the significant variations in educational settings among countries, in the end, the educational challenges and issues that schoolteachers face in the 
Americas and in Europe do not differ greatly. Hence, teachers' beliefs may be able to be generalised internationally, as the teachers encounter similar situations in their schools.

Among the main limitations of the study are, first, the form of access to the sample and size of the sample. Access to the sample was carried out in a non-random manner, when ideally the sample should have been accessed in a completely random manner without compromising the validity of the study (Copas \& Li, 1997). Also, although the size of the sample was not negligible, it did not represent $1 \%$ of the population under study, which, therefore, necessitates caution when considering the results (VanVoorhis \& Morgan, 2007). Moreover, although the results can be considered representative for the teaching population of Europe and North and South America, considering the absence of statistically significant differences by regions, the results, and conclusions of this study cannot be extrapolated to a worldwide population (Olejnik, 1984). Additionally, although the results in terms of reliability and goodness- and badness-of-fit indices were correct for several authors, the most demanding researchers in the field may consider them improvable (Rose et al., 2017).

Schoolteachers' beliefs regarding the seven factors of motivation, evaluation, socioemotional aspects, classroom climate, the teacher's role, methodology, and the student's role were mostly positive. These positive beliefs can be explained by the purely vocational character to which teaching is linked. However, significant differences existed in teachers' beliefs about the importance of the seven factors noted. For example, findings indicated that teachers' beliefs about factors such as evaluation, classroom climate, the teacher's role, and the student's role were less positive than for factors such as motivation, methodology and socioemotional aspects. The teaching environment and the level of freedom are the main reasons for these differences in teachers' beliefs. Considering this, the conclusion can be drawn that the teaching environment may significantly affect teachers' beliefs regarding factors such as the teacher's role, the student's role and classroom climate. In addition, greater autonomy for teachers regarding evaluation may have a positive impact on their beliefs towards evaluation. Along these lines, the strong correlations found among the teachers' beliefs on the factors of motivation, student's role, and classroom climate must be considered.

A progressive decline in teachers' beliefs as they advanced in age and years of experience is evident in the findings. This decline is explained by the fact that older and more experienced professionals are more likely to have encountered stressful situations while teaching that have affected their job satisfaction, altering their beliefs. The most affected factors in this sense were the beliefs regarding the classroom climate and the teacher's role.

The conclusion that women have more positive global beliefs than men, mainly due to their more inclusive nature, is valid. Also valid is the conclusion that employment status does not have a significant influence on teachers' beliefs, as they may have taught for years or they may be aware of the current educational issues in their region, regardless of their employment status. 
Finally, despite important differences in cultures, educational settings, and laws among countries, schoolteachers' beliefs in North America, South America, and Europe are very similar. This can be attributed to the similar educational situations and challenges that they face, resulting in beliefs that are also similar from an educational perspective.

The information provided in this article may help researchers worldwide improve our understanding about the teaching and learning beliefs of North and South American, and European schoolteachers. In the policymaking arena, the questionnaire can serve as a tool for articulating national and international development policies that may help all agents included in the education system. A better understanding of teachers' beliefs will facilitate educational institutions' design and development of programmes that may improve these beliefs. Teachers' positive beliefs are expected to have a positive influence on students' academic performance, perceptions, and well-being. In addition, teachers' psychological well-being is crucial in the educative system. Hence, quantifying factors such as motivation, perceived roles, and other socioemotional aspects may help improve teachers' quality of life and teaching efficacy.

\section{References}

Alansari, M., \& Rubie-Davies, C. (2019). What about the tertiary climate? Reflecting on five decades of class climate research. Learning Environments Research, 1-25. https://doi. org/10.1007/s10984-019-09288-9

Aragona-Young, E., \& Sawyer, B. E. (2018). Elementary teachers' beliefs about multicultural education practices. Teachers and Teaching, 24(5), 465-486. https://doi.org/10.1080/13540602.2018.1435527 Aven, T., Baraldi, P., Flage, R., \& Zio, E. (2013). Uncertainty in risk assessment: the representation and treatment of uncertainties by probabilistic and non-probabilistic methods. New York, NY: John Wiley \& Sons.

Baghestani, A. R., Ahmadi, F., Tanha, A., \& Meshkat, M. (2019). Bayesian critical values for Lawshe's content validity ratio. Measurement and Evaluation in Counseling and Development, 52(1), 69-73. https://doi.org/10.1080/07481756.2017.1308227

Barkatsas, A. T., \& Malone, J. (2005). A typology of mathematics teachers' beliefs about teaching and learning mathematics and instructional practices. Mathematics Education Research Journal, 17(2), 69-90. https://doi.org/10.1007/BF03217416

Barnes, N., Fives, H., \& Dacey, C. M. (2015). Teachers' beliefs about assessment. In H. Fives \& M.G. Gill(Eds.), International handbook of research on teachers' beliefs (pp. 284-300). London, UK: Routledge.

Battersby, S. L., \& Cave, A. (2014). Preservice classroom teachers' preconceived attitudes, confidence, beliefs, and self-efficacy toward integrating music in the elementary curriculum. Update: Applications of Research in Music Education, 32(2), 52-59. https://doi. org $/ 10.1177 / 8755123314521033$ 
Bauman, S., \& Del Río, A. (2005). Knowledge and beliefs about bullying in schools: Comparing preservice teachers in the United States and the United Kingdom. School Psychology International, 26(4), 428-442. https://doi.org/10.1177/0143034305059019

Bereczki, E. O., \& Karpati, A. (2018). Teachers' beliefs about creativity and its nurture: A systematic review of the recent research literature. Educational Research Review, 23, 25-56. https://doi. org/10.1016/j.edurev.2017.10.003

Berger, J. L., \& Lê Van, K. (2019). Teacher professional identity as multidimensional: mapping its components and examining their associations with general pedagogical beliefs. Educational Studies, 45(2), 163-181. 1-19. https://doi.org/10.1080/03055698.2018.1446324

Bernard, M. E. (2016). Teacher beliefs and stress. Journal of Rational-Emotive \& Cognitive-Behavior Therapy, 34(3), 209-224. https://doi.org/10.1007/s10942-016-0238-y

Beswick, K., Wright, S., Watson, J., Hay, I., Allen, J., \& Cranston, N. (2019). Teachers' beliefs related to secondary school completion: associations with socio-educational advantage and school level. The Australian Educational Researcher, 1-24. https://doi.org/10.1007/s13384-019-00317-3

Bishara, A. J., \& Hittner, J. B. (2015). Reducing bias and error in the correlation coefficient due to nonnormality. Educational and Psychological Measurement, 75(5), 785-804. https://doi. org/10.1177/0013164414557639

Blazar, D., \& Kraft, M. A. (2017). Teacher and teaching effects on students' attitudes and behaviors. Educational Evaluation and Policy Analysis, 39(1), 146-170. https://doi. org/10.3102/0162373716670260

Booth, T., \& Ainscow, M. (2000). Index for inclusion. United Kingdom: Centre for Studies on Inclusive Education

Bryan, L. A. (2012). Research on science teacher beliefs. In B. J. Fraser, K. Tobin \& C. J. McRobbie (Eds.), Second international handbook of science education (pp. 477-495). Dordrecht, Holland: Springer. https://doi.org/10.1007/978-1-4020-9041-7 33

Burić, I., Slišković, A., \& Penezić, Z. (2019). Understanding teacher well-being: a cross-lagged analysis of burnout, negative student-related emotions, psychopathological symptoms, and resilience. Educational Psychology, 1-20. https://doi.org/10.1080/01443410.2019.1577952

Calderhead, J. (1996). Teachers: Beliefs and knowledge. In D. Berliner, \& R. Calfee (Eds.). Handbook of Educational Psychology (pp. 709-725). New York: Macmillan Library Reference.

Caprara, G. V., Barbaranelli, C., Steca, P., \& Malone, P. S. (2006). Teachers' self-efficacy beliefs as determinants of job satisfaction and students' academic achievement: A study at the school level. Journal of school psychology, 44(6), 473-490. https://doi.org/10.1016/j.jsp.2006.09.001

Chróinín, D. N., \& O’Sullivan, M. (2016). Elementary classroom teachers' beliefs across time: Learning to teach Physical Education. Journal of Teaching in Physical Education, 35(2), 97-106. https://doi.org/10.1123/jtpe.2015-0030

Collie, R. J., Shapka, J. D., Perry, N. E., \& Martin, A. J. (2015). Teachers' beliefs about social-emotional learning: Identifying teacher profiles and their relations with job stress and satisfaction. Learning and Instruction, 39, 148-157. https://doi.org/10.1016/j.learninstruc.2015.06.002 
Connolly, P. (2007). Quantitative data analysis in education: A critical introduction using SPSS. London, UK: Routledge. doi: https://doi.org/10.4324/9780203946985

Copas, J. B., \& Li, H. G. (1997). Inference for non-random samples. Journal of the Royal Statistical Society: Series B (Statistical Methodology), 59(1), 55-95. https://doi.org/10.1111/1467-9868.00055

Crosswaite, M., \& Asbury, K. (2019). Teacher beliefs about the aetiology of individual differences in cognitive ability, and the relevance of behavioural genetics to education. British Journal of Educational Psychology, 89(1), 95-110. https://doi.org/10.1111/bjep.12224

De Kock, A., Sleegers, P., \& Voeten, M. J. M. (2004). New learning and the classification of learning environments in secondary education. Review of Educational Research, 74, 141-170. https:// doi.org/10.3102/00346543074002141

Debreli, E. (2012). Change in beliefs of pre-service teachers about teaching and learning English as a foreign language throughout an undergraduate pre-service teacher training program. Procedia-Social and Behavioral Sciences, 46, 367-373. https://doi.org/10.1016/j. sbspro.2012.05.124

Deng, F., Chai, C. S., Tsai, C.-C., \& Lee, M.-H. (2014). The Relationships among Chinese Practicing Teachers' Epistemic Beliefs, Pedagogical Beliefs and Their Beliefs about the Use of ICT. Educational Technology \& Society, 17 (2), 245-256.

Dellinger, A. B., Bobbett, J. J., Olivier, D. F., \& Ellett, C. D. (2008). Measuring teachers' self-efficacy beliefs: Development and use of the TEBS-Self. Teaching and teacher education, 24(3), 751-766. https://doi.org/10.1016/j.tate.2007.02.010

Drost, E. A. (2011). Validity and reliability in social science research. Education Research and perspectives, 38(1), 105.

Dubbeld, A., De Hoog, N., Den Brok, P., \& de Laat, M. (2019). Teachers' multicultural attitudes and perceptions of school policy and school climate in relation to burnout. Intercultural Education, 1-19. https://doi.org/10.1080/14675986.2018.1538042

Duchesne, S., \& McMaugh, A. (2018). Educational psychology for learning and teaching. Sidney, Australia: Cengage.

Duckworth, A. L., \& Yeager, D. S. (2015). Measurement matters: Assessing personal qualities other than cognitive ability for educational purposes. Educational Researcher, 44(4), 237-251. https://doi.org/10.3102/0013189X15584327

Emmanuel, D. T. (2005). The effects of a music education immersion internship in a culturally diverse setting on the beliefs and attitudes of pre-service music teachers. International Journal of Music Education, 23(1), 49-62. https://doi.org/10.1177/0255761405050930

Ertmer, P. A. (2005). Teacher pedagogical beliefs: The final frontier in our quest for technology integration? Educational technology research and development, 53(4), 25-39. https://doi. org/10.1007/BF02504683

Etikan, I., Musa, S. A., \& Alkassim, R. S. (2016). Comparison of convenience sampling and purposive sampling. American Journal of Theoretical and Applied Statistics, 5(1), 1-4. https:// doi.org//0.11648/j.ajtas.20160501.11 
Farrell, T. S., \& Lim, P. C. P. (2005). Conceptions of Grammar Teaching: A Case Study of Teachers' Beliefs and Classroom Practices. The Electronic Journal for English as a Second Language Tesl-Ej, 9(2), 1-13.

Fives, H., Hamman, D., \& Olivarez, A. (2007). Does burnout begin with student-teaching? Analyzing efficacy, burnout, and support during the student-teaching semester. Teaching and Teacher Education, 23(6), 916-934. https://doi.org/10.1016/j.tate.2006.03.013

Fives, H., Lacatena, N., \& Gerard, L. (2015). Teachers' beliefs about teaching (and learning). In H. Fives \& M. G. Gill (Eds.), International handbook of research on teachers' beliefs (pp. 249265). London, UK: Routledge.

Gerbing, D. W., \& Hamilton, J. G. (1996). Viability of exploratory factor analysis as a precursor to confirmatory factor analysis. Structural Equation Modeling: A Multidisciplinary Journal, 3(1), 62-72. https://doi.org/10.1080/10705519609540030

Gill, M. G., Ashton, P. T., \& Algina, J. (2004). Changing preservice teachers' epistemological beliefs about teaching and learning in mathematics: An intervention study. Contemporary Educational Psychology, 29(2), 164-185. https://doi.org/10.1016/j.cedpsych.2004.01.003

Glackin, M. (2016). 'Risky fun'or 'Authentic science'? How teachers' beliefs influence their practice during a professional development programme on outdoor learning. International Journal of Science Education, 38(3), 409-433. https://doi.org/10.1080/09500693.2016.1145368

Gralewski, J. (2019). Teachers' beliefs about creative students' characteristics: A qualitative study. Thinking Skills and Creativity, 31, 138-155. https://doi.org/10.1016/j.tsc.2018.11.008

Granziera, H., \& Perera, H. N. (2019). Relations among teachers' self-efficacy beliefs, engagement, and work satisfaction: A social cognitive view. Contemporary Educational Psychology, 58, 75-84. https://doi.org/10.1016/j.cedpsych.2019.02.003

Hancock, E. S., \& Gallard, A. J. (2004). Preservice science teachers' beliefs about teaching and learning: The influence of K-12 field experiences. Journal of Science Teacher Education, 15(4), 281-291. https://doi.org/10.1023/B:JSTE.0000048331.17407.f5

Haynes, C. A., \& Shelton, K. (2018). Delphi method in a digital age: Practical considerations for online Delphi studies. In V. C. Wang \& T. J. Reio Jr (Eds.), Handbook of research on innovative techniques, trends, and analysis for optimized research methods (pp. 132-151). IGI Global.

Huang, S., Yin, H., \& Lv, L. (2019). Job characteristics and teacher well-being: the mediation of teacher self-monitoring and teacher self-efficacy. Educational Psychology, 39(3), 313-331. https://doi.org/10.1080/01443410.2018.1543855

Kelley, K., Bilson Darku, F., \& Chattopadhyay, B. (2019). Sequential accuracy in parameter estimation for population correlation coefficients. Psychological methods 24(4), 492515. https://doi.org/10.1037/met0000203

Kline, P. (2015). A handbook of test construction (psychology revivals): introduction to psychometric design. London, UK: Routledge.https://doi.org/10.4324/9781315695990

Koballa, T. R., \& Crawley, F. E. (1989). The influence of attitude on science teaching and learning. School, Science and Mathematics, 85, 222-232. 
Köğce, D. (2017). A study of pre-service classroom teachers' beliefs about teachers' and students' roles. International Journal of Mathematical Education in Science and Technology, 48(6), 830-848. https://doi.org/10.1080/0020739X.2016.1276228

Kurup, P. M., Li, X., Powell, G., \& Brown, M. (2019). Building future primary teachers' capacity in STEM: based on a platform of beliefs, understandings and intentions. International Journal of STEM Education, 6(1). https://doi.org/10.1186/s40594-019-0164-5

Lakens, D. (2017). Equivalence tests: a practical primer for t tests, correlations, and metaanalyses. Social Psychological and Personality Science, 8(4), 355-362. https://doi. org/10.1177/1948550617697177

Lee, S. J., \& Branch, R. M. (2018). Students' beliefs about teaching and learning and their perceptions of student-centred learning environments. Innovations in Education and Teaching International, 55(5), 585-593. https://doi.org/10.1080/14703297.2017.1285716

Lev, S., Tatar, M., \& Koslowsky, M. (2018). Teacher self-efficacy and students' ratings. International Journal of Educational Management, 32(3), 498-510. https://doi.org/10.1108/IJEM-10-2016$\underline{0206}$

Little, S., Golledge, M., Agarwalla, H., Griffiths, B., \& McCamlie, D. (2019). Global teachers as global learners: Intercultural teacher training in international settings. London Review of Education, 17(1), 38-51. https://doi.org/10.18546/LRE.17.1.04

Lotter, C. R., Thompson, S., Dickenson, T. S., Smiley, W. F., Blue, G., \& Rea, M. (2018). The impact of a practice-teaching professional development model on teachers' inquiry instruction and inquiry efficacy beliefs. International Journal of Science and Mathematics Education, 16(2), 255-273. https://doi.org/10.1007/s10763-016-9779-x

Mansilla, J. y Beltrán, J. (2013). Coherencia entre las estrategias didácticas y las creencias curriculares de los docentes de segundo ciclo, a partir de las actividades didácticas. Perfiles Educativos, 35(139), 25-39. https://doi.org/10.1016/S0185-2698(13)71807-5

Marshall, G., \& Cox, M. J. (2008). Research methods: Their design, applicability and reliability. In International handbook of information technology in primary and secondary education (pp. 983-1002). Springer: Boston, MA. https://doi.org/10.1007/978-0-387-73315-9 62

McCombs, B. \& Whisler, J. (1997). La clase y la escuela centrada en el aprendiz: Estrategias para aumentar la motivación y el rendimiento. Barcelona: Paidós.

McCrae, R. R., Kurtz, J. E., Yamagata, S., \& Terracciano, A. (2011). Internal consistency, retest reliability, and their implications for personality scale validity. Personality and Social Psychology Review, 15(1), 28-50. https://doi.org/10.1177/1088868310366253

Oder, T., \& Eisenschmidt, E. (2018). Teachers' perceptions of school climate as an indicator of their beliefs of effective teaching. Cambridge Journal of Education, 48(1), 3-20. https://doi. org/10.1080/0305764X.2016.1223837

Olejnik, S. F. (1984). Planning educational research: Determining the necessary sample size. The Journal of Experimental Education, 53(1), 40-48. https://doi.org/10.1080/00220973.1984. $\underline{10806360}$ 
Oluwatayo, J. A. (2012). Validity and reliability issues in educational research. Journal of Educational and Social Research, 2(2), 391-400. http://doi.org//10.5901/jesr.2012.v2n2.391

O’Neal, L. J., Gibson, P., \& Cotten, S. R. (2017). Elementary school teachers' beliefs about the role of technology in 21st-century teaching and learning. Computers in the Schools, 34(3), 192-206. https://doi.org/10.1080/07380569.2017.1347443

Oppermann, E., Brunner, M., \& Anders, Y. (2019). The interplay between preschool teachers' science self-efficacy beliefs, their teaching practices, and girls' and boys' early science motivation. Learning and Individual Differences, 70, 86-99. https://doi.org/10.1016/j. lindif.2019.01.006

Osborne, J. W. (2003). Effect sizes and the disattenuation of correlation and regression coefficients: lessons from educational psychology. Practical Assessment, Research \& Evaluation, 8(11), 1-5. https://doi.org/10.7275/0k9h-tq64

Osborne, J. W. (2015). What is rotating in exploratory factor analysis. Practical assessment, research \& evaluation, 20(2), 1-7. https://doi.org/10.7275/hb2g-m060

Osborne, J. W., Costello, A. B., \& Kellow, J. T. (2008). Best practices in exploratory factor analysis. In J.W. Osborne (Ed.), Best practices in quantitative methods (pp. 86-99). Thousand Oaks, CA: SAGE Publications. http://doi.org//10.4135/9781412995627.d8

Pajares, M. F. (1992). Teachers' beliefs and educational research: Cleaning up a messy construct. Review of Educational Research, 62(3), 307-332. https://doi.org/10.3102/00346543062003307

Peterson, E. R., Rubie-Davies, C., Osborne, D., \& Sibley, C. (2016). Teachers' explicit expectations and implicit prejudiced attitudes to educational achievement: Relations with student achievement and the ethnic achievement gap. Learning and Instruction, 42, 123-140. https:// doi.org/10.1016/j.learninstruc.2016.01.010

Phipps, S., \& Borg, S. (2009). Exploring tensions between teachers' grammar teaching beliefs and practices. System, 37(3), 380-390. https://doi.org/10.1016/j.system.2009.03.002

Prawat, R. S. (1992). Teachers' beliefs about teaching and learning: A constructivist perspective. American Journal of Education, 100(3), 354-395. Retrieved from http://www.jstor.org/ $\underline{\text { stable/1085493 }}$

Raymond, A. M. (1997). Inconsistency between a beginning elementary school teacher's mathematics beliefs and teaching practice. Journal for research in mathematics education, 28(5), 550-576. https://doi.org/10.5951/jresematheduc.28.5.0550

Reich, J. (2015). Rebooting MOOC research. Science, 347(6217), 34-35. http://doi.org/10.1126/ science. 1261627

Reichert, F., \& Torney-Purta, J. (2019). A cross-national comparison of teachers' beliefs about the aims of civic education in 12 countries: A person-centered analysis. Teaching and Teacher Education, 77, 112-125. https://doi.org/10.1016/j.tate.2018.09.005

Reyes, M. R., Brackett, M. A., Rivers, S. E., Elbertson, N. A., \& Salovey, P. (2012). The interaction effects of program training, dosage, and implementation quality on targeted student outcomes for the RULER approach to social and emotional learning. School Psychology Review, 41(1), 82-99. https://doi.org/10.1080/02796015.2012.12087377 
Richardson, V., Anders, P., Tidwell, D., \& Lloyd, C. (1991). The relationship between teachers' beliefs and practices in reading comprehension instruction. American Educational Research Journal, 28(3), 559-586. https://doi.org/10.3102/00028312028003559

Roose, I., Vantieghem, W., Vanderlinde, R., \& Van Avermaet, P. (2019). Beliefs as filters for comparing inclusive classroom situations. Connecting teachers' beliefs about teaching diverse learners to their noticing of inclusive classroom characteristics in videoclips. Contemporary Educational Psychology, 56, 140-151. https://doi.org/10.1016/j.cedpsych.2019.01.002

Rose, S. A., Markman, B., \& Sawilowsky, S. (2017). Limitations in the Systematic Analysis of Structural Equation Model Fit Indices. Journal of Modern Applied Statistical Methods, 16(1), 69-85. http://doi.org/10.22237/jmasm/1493597040

Rubie-Davies, C. (2015). Teachers' instructional beliefs and the classroom climate. In H. Fives \& M.G. Gill (Eds.), International handbook of research on teachers' beliefs (pp. 266-283). London, UK: Routledge.

Rubie-Davies, C. M., \& Peterson, E. R. (2010). Teacher expectations and beliefs: Influences on the socioemotional environment of the classroom. In C.M. Rubie-Davis (Ed.), Educational psychology: Concepts, research and challenges (pp. 148-163). London, UK: Routledge. http:// doi.org/10.4324/9780203838884

Sak, R., Şahin Sak, İ. T., \& Yerlikaya, İ. (2015). Behavior management strategies: Beliefs and practices of male and female early childhood teachers. European Early Childhood Education Research Journal, 23(3), 328-339. https://doi.org/10.1080/1350293X.2015.1043807

Sak, R., Tantekin-Erden, F., \& Morrison, G. S. (2018). Preschool teachers' beliefs and practices related to child-centred education in Turkey. Education 3-13, 46(5), 563-577. https://doi.org/ $\underline{10.1080 / 03004279.2017 .1322995}$

Samuelowicz, K., \& Bain, J. D. (2001). Revisiting academics' beliefs about teaching and learning. Higher Education, 41(3), 299-325. https://doi.org/10.1023/A:1004130031247

Santos, D., \& Miguel, L. (2019). The relationship between teachers' beliefs, teachers' behaviors, and teachers' professional development: A Literature Review. International Journal of Education and Practice, 7(1), 10-18. http://doi.org/10.18488/journal.61.2019.71.10.18

Schraw, G., \& Olafson, L. (2015). Assessing teachers' beliefs. In H. Fives \& M.G. Gill (Eds.), International handbook of research on teachers' beliefs (pp. 87-105). London, UK: Routledge.

Shahzad, A. H., Hussain, I., Ali, R., Valcke, M., \& Khurshid, K. (2017). Typologies of didactical strategies and teachers' pedagogical beliefs: a theoretical review. Eurasia Journal of Mathematics Science and Technology Education, 13(10), 6583-6596. http://doi.org/10.12973/ejmste/78159

Sharma, U., \& Sokal, L. (2015). The impact of a teacher education course on pre-service teachers' beliefs about inclusion: an international comparison. Journal of Research in Special Educational Needs, 15(4), 276-284. https://doi.org/10.1111/1471-3802.12043

Sharma, U., Aiello, P., Pace, E. M., Round, P., \& Subban, P. (2018). In-service teachers' attitudes, concerns, efficacy and intentions to teach in inclusive classrooms: An international comparison of Australian and Italian teachers. European Journal of Special Needs Education, 33(3), 437-446. https://doi.org/10.1080/08856257.2017.1361139 
Shuell, T. J. (1996). The role of educational psychology in the preparation of teachers. Educational Psychologist, 31, 5-14. https://doi.org/10.1207/s15326985ep3101 1

Skaalvik, E. M., \& Skaalvik, S. (2017). Motivated for teaching? Associations with school goal structure, teacher self-efficacy, job satisfaction and emotional exhaustion. Teaching and Teacher Education, 67, 152-160. https://doi.org/10.1016/j.tate.2017.06.006

Solis, C. A. (2015). Creencias sobre enseñanza y aprendizaje en docentes universitarios: Revisión de algunos estudios. Propósitos y Representaciones, 3(2), 227-260.

Specht, J., McGhie-Richmond, D., Loreman, T., Mirenda, P., Bennett, S., Gallagher, T., Young, G., Metsala, J., \& Lyons, W. (2016). Teaching in inclusive classrooms: Efficacy and beliefs of Canadian preservice teachers. International Journal of Inclusive Education, 20(1), 1-15. https:// doi.org/10.1080/13603116.2015.1059501

Tam, A. C. F. (2015). The role of a professional learning community in teacher change: A perspective from beliefs and practices. Teachers and Teaching, 21(1), 22-43. https://doi.org/ 10.1080/13540602.2014.928122

Tella, A. (2017). Teacher variables as predictors of academic achievement of primary school pupils mathematics. International Electronic Journal of Elementary Education, 1(1), 16-33.

Teo, T., \& Zhou, M. (2017). The influence of teachers' conceptions of teaching and learning on their technology acceptance. Interactive Learning Environments, 25(4), 513-527. https://doi. org/10.1080/10494820.2016.1143844

Thomas, M. (2013). Teachers' beliefs about classroom teaching-teachers' knowledge and teaching approaches. Procedia-Social and Behavioral Sciences, 89, 31-39. https://doi.org/10.1016/j. sbspro.2013.08.805

Thompson, L. K. (2007). Considering beliefs in learning to teach music. Music Educators Journal, 93(3), 30-35. https://doi.org/10.1177/002743210709300317

Trigwell, K. \& Prosser, M. (1991). Improving the quality of student learning: the influence of learning context and student learning outcomes. Higher Education, 22, 251-266. https://doi. org/10.1007/BF00132290

Tsai, C. C. (2002). Nested epistemologies: science teachers' beliefs of teaching, learning and science. International Journal of Science Education, 24(8), 771-783. https://doi. org/10.1080/09500690110049132

Tsangaridou, N. (2017). Early childhood teachers' views about teaching physical education: challenges and recommendations. Physical Education and Sport Pedagogy, 22(3), 283-300. https://doi.org/10.1080/17408989.2016.1192593

Tschannen-Moran, M., \& Hoy, A. W. (2007). The differential antecedents of self-efficacy beliefs of novice and experienced teachers. Teaching and teacher Education, 23(6), 944-956. https:// doi.org/10.1016/j.tate.2006.05.003

Tschannen-Moran, M., \& Johnson, D. (2011). Exploring literacy teachers' self-efficacy beliefs: Potential sources at play. Teaching and Teacher Education, 27(4), 751-761. https://doi. org/10.1016/j.tate.2010.12.005 
Van Voorhis, C. W., \& Morgan, B. L. (2007). Understanding power and rules of thumb for determining sample sizes. Tutorials in Quantitative Methods for Psychology, 3(2), 43-50. http://doi.org/10.20982/tqmp.03.2.p043

Virta, A. (2002). Becoming a history teacher: observations on the beliefs and growth of student teachers. Teaching and Teacher Education, 18(6), 687-698. https://doi.org/10.1016/S0742051X(02)00028-8

Voet, M., \& De Wever, B. (2016). History teachers' conceptions of inquiry-based learning, beliefs about the nature of history, and their relation to the classroom context. Teaching and Teacher Education, 55, 57-67. https://doi.org/10.1016/j.tate.2015.12.008

Walker, S., \& Graham, L. (2019). At risk students and teacher-student relationships: student characteristics, attitudes to school and classroom climate. International Journal of Inclusive Education, 1-18. https://doi.org/10.1080/13603116.2019.1588925

Warwas, J., \& Helm, C. (2018). Professional learning communities among vocational school teachers: Profiles and relations with instructional quality. Teaching and teacher education, 73, 43-55. https://doi.org/10.1016/j.tate.2018.03.012

Wilson, F. R., Pan, W., \& Schumsky, D. A. (2012). Recalculation of the critical values for Lawshe's content validity ratio. Measurement and evaluation in counseling and development, 45(3), 197-210. https://doi.org/10.1177/0748175612440286

Yan, Z. (2018). How teachers' beliefs and demographic variables impact on self-regulated learning instruction. Educational Studies, 44(5), 564-577. https://doi.org/10.1080/03055698.2017.1382331

Yigit, S., \& Mendes, M. (2018). Which effect size measure is appropriate for one-way and two-way ANOVA models? A Monte Carlo simulation study. Revstat Statistical Journal, 16, 295-313.

Yuan, K. H., Chan, W., Marcoulides, G. A., \& Bentler, P. M. (2016). Assessing structural equation models by equivalence testing with adjusted fit indexes. Structural Equation Modeling: A Multidisciplinary Journal, 23(3), 319-330. https://doi.org/10.1080/10705511.2015.1065414 


\title{
Pedagoginių ịsitikinimų apie mokymo praktiką plètros ir patvirtinimo klausimynas: tarpžemyninis tyrimas
}

\author{
Lidon Moliner ${ }^{1}$, Aida Sanahuja ${ }^{2}$, Francisco Alegre $^{3}$ \\ Jaume I universitetas, Pedagogikos katedra, Sos Baynat aleja s/n 12071, Kasteljonas, Ispanija, mmoliner@uji.es \\ Jaume I universitetas, Pedagogikos katedra, Sos Baynat alèja, s/n 12071, Kasteljonas, Ispanija, asanahuj@uji.es \\ Jaume I universitetas, Pedagogikos katedra, Sos Baynat alejja s/n 12071, Kasteljonas, Ispanija, falegre@uji.es
}

\section{Santrauka}

Šio tyrimo tikslas - sukurti ir patvirtinti klausimyną, skirtą įvertinti mokytojų pedagoginius ìsitikinimus. Tyrime dalyvavo 641 mokytojas ir 26 ekspertai. Klausimyne pateikta septynių faktorių struktūra, pagal kuriuos vertinami mokytojų ísitikinimai. Septyni faktoriai buvo šie: (1) motyvacija, (2) įvertinimas, (3) socialiniai ir emociniai aspektai, (4) klimatas klasėje, (5) mokytojo vaidmuo, (6) metodologija ir (7) mokytojo vaidmuo. Mokytojų atsakymams $\mathfrak{i}$ kiekvieną teiginį buvo taikoma 5 balų Likerto skalè. Matavimo skalès Cronbacho alfa -.91 . Šio tyrimo tikslai buvo dvejopi: 1) sukurti ir patvirtinti klausimyną, kuriame būtų galima išnagrinèti mokytojų pedagoginius įsitikinimus; 2) išanalizuoti rezultatus, gautus pritaikius klausimyną. Siekiant šių tikslų, pasiūlyti šie tyrimo klausimai: Kokie yra mokytojų pedagoginiai įsitikinimai apie mokymo praktiką? Ar yra statistiškai reikšmingų skirtumų tarp mokytojų pedagoginių įsitikinimų, susijusių su mokymo praktika, remiantis ilgamete patirtimi, lytimi, užimtumo padetimi ir kvalifikacija? Palyginti su vyresniais, labiau patyrusiais tyrimo dalyviais, taip pat vyrais, atitinkamai jaunesnès, mažiau patyrusios tyrimo dalyvės, taip pat moterys, pademonstravo daugiau teigiamų įsitikinimų apie tokius faktorius kaip klimatas klaseje, mokytojo vaidmuo ir mokinio vaidmuo.

Esminiai žodžiai: mokytojai, pedagoginiai įsitikinimai, klausimynas. 


\section{Appendices}

\section{Schoolteachers' pedagogical beliefs on teaching practices questionnaire}

Scale: 1 = strongly disagree, 2 = disagree, 3 = indifferent, $4=$ agree, $5=$ strongly agree

Factors: $1=$ motivation, $2=$ evaluation, $3=$ socioemotional aspects, $4=$ classroom climate, 5 = teacher's role, $6=$ methodology, 7 = student's role

\begin{tabular}{|c|c|c|}
\hline Item & Sentence & Factor \\
\hline 1 & $\begin{array}{l}\text { Activities should be developed considering the interests and motivations } \\
\text { of the students. }\end{array}$ & 1 \\
\hline 2 & $\begin{array}{l}\text { Teachers must have enough strategies to motivate all students, even those } \\
\text { who do not have interest. }\end{array}$ & 1 \\
\hline 3 & $\begin{array}{l}\text { Some students are unmotivated because the centres have not answered } \\
\text { their interests or expectations. }\end{array}$ & 1 \\
\hline 4 & Teachers must create a classroom climate that students enjoy. & 1 \\
\hline 5 & $\begin{array}{l}\text { The evaluation of the students must be diversified and adapted to the } \\
\text { personal characteristics of each student. }\end{array}$ & 2 \\
\hline 6 & $\begin{array}{l}\text { The final evaluation supposes a stressor for the students; therefore, it should } \\
\text { be eliminated. }\end{array}$ & 2 \\
\hline 7 & $\begin{array}{l}\text { The time given for the evaluation should adapt to the rhythms of the } \\
\text { students. }\end{array}$ & 2 \\
\hline 8 & Teachers should look for different ways to evaluate students. & 2 \\
\hline 9 & $\begin{array}{l}\text { The adequate socioemotional development of students must be prioritised } \\
\text { over their cognitive-intellectual development. }\end{array}$ & 3 \\
\hline 10 & $\begin{array}{l}\text { Teaching staff should promote and develop students' personal knowledge } \\
\text { as well as healthy relationships among them. }\end{array}$ & 3 \\
\hline 11 & Tutoring is as important as classroom work. & 3 \\
\hline 12 & Self-concept is vital and necessary for student learning. & 3 \\
\hline 13 & Faculty must focus on creating a friendly classroom climate. & 4 \\
\hline 14 & $\begin{array}{l}\text { Relationships between teachers and students should be horizontal and } \\
\text { democratic. }\end{array}$ & 4 \\
\hline 15 & The teacher's role is a determining factor in student learning. & 5 \\
\hline 16 & $\begin{array}{l}\text { Making a connection between the previous knowledge of the student and } \\
\text { the new content to be learned should be a task carried out by the teacher, } \\
\text { even if this implies delaying the introduction of the new content. }\end{array}$ & 5 \\
\hline 17 & The teacher is responsible for the degree of learning of all students. & 5 \\
\hline 18 & Cooperative learning allows students to learn more and better. & 6 \\
\hline 19 & $\begin{array}{l}\text { Learning objectives should be broken down into more basic components } \\
\text { to meet the diversity of classroom learning. }\end{array}$ & 6 \\
\hline
\end{tabular}




\begin{tabular}{llc}
\hline Item & \multicolumn{1}{c}{ Sentence } & Factor \\
\hline 20 & $\begin{array}{l}\text { The teacher must have sufficient reinforcements to ensure that all students } \\
\text { learn. }\end{array}$ & 6 \\
21 & $\begin{array}{l}\text { Students must be the protagonists of teaching-learning processes. } \\
22\end{array}$ & 7 \\
& $\begin{array}{l}\text { Teachers' empathy with students is closely linked to the students' academic } \\
\text { performance. }\end{array}$ & 7 \\
23 & $\begin{array}{l}\text { Students' satisfaction is closely related to the teaching-learning processes } \\
\text { that take place in the classroom. }\end{array}$ & 7 \\
24 & $\begin{array}{l}\text { Learning objectives should be developed in a democratic way between } \\
\text { teachers and students. }\end{array}$ & 7 \\
25 & $\begin{array}{l}\text { Students' opinions should be considered when making decisions. } \\
26\end{array}$ & $\begin{array}{l}\text { Lack of flexibility in the educational system is an obstacle in the learning } \\
\text { process of the student. }\end{array}$ \\
\end{tabular}

Gauta 20200507 / Received 07052020

Priimta 20210913 / Accepted 13092021 